\title{
Penggunaan UPFC (Unified Power Flow Controller) untuk Perbaikan Kestabilan Sistem Tenaga Listrik yang Terinterkoneksi
}

\author{
Rudy Gianto \\ Jurusan Teknik Elektro Universitas Tanjungpura, Pontianak \\ Jl. Prof. Dr. H. Hadari Nawawi Pontianak 78124 \\ rudy.giantodee.untan.ac.id
}

Intisari - Makalah ini membahas penggunaan peralatan FACTS (Flexible AC Transmission Systems) untuk meningkatkan atau memperbaiki kestabilan sistem tenaga listrik yang terinterkoneksi. Peralatan FACTS pada umumnya digunakan untuk mengendalikan aliran daya-aktif dan/atau daya-reaktif serta untuk mengontrol besarnya tegangan sistem. Namun demikian, dengan memasang alat kontrol tambahan, peralatan FACTS dapat digunakan untuk meningkatkan redaman elektromekanik dan kestabilan sistem tenaga listrik sebagai fungsi sekundernya. Salah satu peralatan FACTS yang cukup populer saat ini adalah UPFC (Unified Power Flow Controller). UPFC merupakan peralatan FACTS generasi ketiga. Peralatan ini menggabungkan kompensator shunt dan kapasitor seri statik menjadi satu peralatan dengan sistem kendali terpadu. UPFC memiliki kemampuan unik untuk mengendalikan aliran daya listrik dan tegangan secara simultan sehingga memiliki potensi untuk digunakan dalam meningkatkan redaman dan kestabilan sistem. Makalah ini menyelidiki aplikasi dari UPFC pada peningkatan kestabilan sistem tenaga listrik yang terinterkoneksi. Keefektifan dari peralatan tersebut dalam memperbaiki penampilan dinamik dan meningkatkan kestabilan suatu sistem tenaga telah dikonfirmasi melalui hasil-hasil perhitungan nilaieigen dan divalidasi dengan menggunakan simulasi domain-waktu.

Kata kunci - FACTS, UPFC, Redaman, Kestabilan, Sistem Tenaga Listrik

Abstract - This paper discusses an application of FACTS (Flexible AC Transmission Systems) device in improving the stability of interconnected electric power system. FACTS devices are used primarily for controlling active- and/or reactive-power and also for voltage regulation. However, by employing some supplementary controllers, it can also be used for enhancing system electromechanical damping and stability as its secondary function. One of the most popular FACTS devices is UPFC (Unified Power Flow Controller). UPFC is a third generation of FACTS device. This device combines the shunt compensator and static series capacitor as one device with a unified control system. UPFC has a unique ability in controlling simultaneously system power flow and voltage, and therefore, has a potential to be used for system damping and stability improvement. This paper investigates an application of UPFC in improving the stability of interconnected power system. The effectiveness of the device in enhancing system dynamic performance and stability has been confirmed through eigenvalue calculations and validated using time-domain simulations.

Keywords - FACTS, UPFC, Damping, Stability, Electric Power System 


\section{PENDAHULUAN}

Sistem tenaga listrik yang berperilaku tidak stabil sangat tidak diinginkan karena merupakan ancaman serius terhadap keamanan sistem tenaga listrik dan akan mengakibatkan operasi dari sistem tersebut menjadi sangat sulit. Pada kasus terburuk, ketidak-stabilan sistem dapat mengakibatkan generator-generator pembangkit daya menjadi kehilangan sinkronisme yang pada gilirannya dapat menyebabkan sistem tenaga menjadi gagal atau kolaps (collapse). Gagalnya sistem tenaga ini akan sangat merugikan karena akan membuat suplai daya listrik ke konsumen menjadi terganggu atau terputus.

Secara konvensional, kestabilan sistem dapat diperbaiki atau ditingkatkan dengan menggunakan peralatan PSS (Power System Stabilizer). PSS merupakan peralatan yang paling populer dan telah lama digunakan untuk meredam osilasi-osilasi elektromekanik yang mengikuti gangguan pada suatu sistem tenaga [1-3]. Namun demikian, dengan semakin membesarnya interkoneksi sistem tenaga dan meningkatnya pembebanan saluran transmisi, penggunaan PSS tidak lagi dapat memberikan redaman yang cukup terhadap osilasi elektromekanik sistem. Pada kasus seperti ini, peralatan lain sebagai tambahan terhadap PSS harus digunakan agar sistem tetap dapat memperoleh redaman yang cukup bila terjadi gangguan [4-10].

Saat ini, banyak sistem tenaga telah dilengkapi dengan peralatan FACTS. Peralatan ini fungsi utamanya adalah untuk mengendalikan aliran daya-aktif dan dayareaktif serta untuk mengontrol besarnya tegangan. Namun demikian, dengan memasang alat kontrol tambahan, peralatan, FACTS dapat digunakan untuk meningkatkan redaman sistem tenaga sebagai fungsi sekundernya. Alat kontrol tambahan ini biasa disebut sebagai FDS (FACTS Device Stabilizer), dan biasanya digabung dengan alat kontrol utama dari peralatan FACTS untuk mendapatkan redaman terhadap osilasi [4-10].
SVC (Static Var Compensator) merupakan peralatan FACTS generasi pertama yang pada umumnya digunakan untuk stabilisasi tegangan dan kompensasi daya reaktif. SVC terdiri dari kapasitor dan/atau reaktor shunt yang dikontrol oleh switch thyristor sehingga dapat memberikan kompensasi shunt secara dinamik [11]. Kompensasi shunt dinamik ini akan secara kontinu menyesuaikan keluaran daya reaktif dan mempertahankan tegangan pada level tertentu yang dikehendaki. Kemampuan SVC dalam mengendalikan daya ini berimplikasi bahwa peralatan tersebut dapat digunakan untuk perbaikan penampilan dinamik sistem [4,5]. Peralatan FACTS generasi pertama berikutnya adalah TCSC (Thyristor Controlled Series Capacitor). TCSC merupakan salah satu jenis peralatan FACTS yang dapat digunakan untuk merubah impedansi saluran transmisi secara cepat dan kontinu dan dapat mengatur aliran daya pada saluran tersebut [11]. Kemampuan TCSC dalam mengatur aliran daya ini juga mengimplikasikan bahwa peralatan ini memiliki potensi untuk digunakan dalam meningkatkan redaman dan kestabilan sistem [7-10].

Peralatan FACTS generasi kedua merupakan peralatan FACTS yang didasarkan pada VSC (Voltage Source Converters). Peralatan FACTS yang termasuk generasi kedua adalah STATCOM (Static Synchronous Compensator) dan SSSC (Static Synchronous Series Compensator) [11]. STATCOM biasanya digunakan untuk mempertahankan stabilitas tegangan, namun dengan peralatan tambahan ia juga bisa digunakan untuk perbaikan penampilan dinamik sistem [6]. Sedangkan SSSC pada dasarnya merupakan versi seri dari STATCOM. Peralatan yang terhubung seri ini dapat mengendalikan aliran daya pada saluran tertentu yang diinginkan sehingga berpotensi digunakan untuk meningkatkan redaman sistem [11].

$\begin{array}{lrrr}\begin{array}{l}\text { Peralatan } \\ \text { merupakan }\end{array} \text { FACTS } & \text { generasi } & \text { kedua } \\ \text { didasarkan pada VSC } & \text { FACTS } & \text { (Voltage } & \text { Sounge } \\ \text { Converters). } & \text { Peralatan } & \text { FACTS yang } \\ \text { termasuk generasi kedua adalah STATCOM } \\ \text { (Static Synchronous Compensator) dan SSSC } \\ \text { (Static Synchronous Series Compensator) }\end{array}$


[11]. STATCOM biasanya digunakan untuk mempertahankan stabilitas tegangan, namun dengan peralatan tambahan ia juga bisa digunakan untuk perbaikan penampilan dinamik sistem [6]. Sedangkan SSSC pada dasarnya merupakan versi seri dari STATCOM. Peralatan yang terhubung seri ini dapat mengendalikan aliran daya pada saluran tertentu yang diinginkan sehingga berpotensi digunakan untuk meningkatkan redaman sistem [11].

\section{MODEL DINAMIK SISTEM TENAGA LISTRIK}

\section{A. Model Dinamik Sistem Multi-Mesin}

Untuk studi kestabilan, model dinamik dari sistem tenaga harus sesuai untuk jangkauan frekwensi dari osilasi elektromekanik yang mungkin terjadi dalam sistem tersebut. Komponen-komponen dinamik dari sistem tenaga seperti mesin-mesin sinkron beserta alat-alat kontrolnya, PSS, FDS dan UPFC akan dimodelkan melalui persamaanpersamaan diferensial. Oleh karena frekwensi dari osilasi elektromekanik adalah rendah, komponen-komponen dari sistem tenaga seperti jaringan transmisi dan transfomator akan dianggap sebagai komponen-komponen statik dan adalah valid untuk dimodelkan melalui persamaan-persamaan aljabar.

Dapat ditunjukkan bahwa model-model dinamik untuk komponen sistem tenaga listrik dapat dinyatakan melalui persamaanpersamaan diferensial orde-pertama. Lebih lanjut, dalam analisis kestabilan, adalah diperlukan untuk merepresentasikan interaksi antara komponen-komponen sistem tersebut yang diinterkoneksikan melalui jaringanjaringan sistem tenaga. Dapat ditunjukkan juga bahwa model jaringan tersebut dapat dinyatakan melalui persamaan-persamaan aljabar. Dengan demikian, kombinasi dari persamaan-persamaan diferensial dan aljabar tersebut merupakan model yang menggambarkan dinamika dari sistem tenaga listrik secara lengkap dalam kaitannya dengan respon-respon elektromekanik.

\section{B. Matriks Keadaan Sistem}

Seperti yang telah diuraikan, model dinamik dari sistem tenaga dapat dinyatakan melalui sekumpulan (set) persamaanpersamaan diferensial-aljabar yang dapat dituliskan secara kompak seperti berikut:

$$
\begin{aligned}
& \dot{\mathbf{x}}=\mathbf{f}(\mathbf{x}, \mathbf{w}) \\
& \mathbf{0}=\mathbf{g}(\mathbf{x}, \mathbf{w})
\end{aligned}
$$

dimana: $\boldsymbol{x}$ adalah vektor dari variabelvariabel keadaan; $\boldsymbol{w}$ adalah vektor dari variabel-variabel non-keadaan (aljabar); $f$ dan $\boldsymbol{g}$ merupakan fungsi-fungsi vector.

Untuk kasus kestabilan gangguan-kecil (small disturbance stability), kombinasi dari persamaan-persamaan diferensial-aljabar tersebut dapat dilinierisasi disekitar disekitar titik operasi tertentu yang akan menghasilkan bentuk umum:

$$
\left(\begin{array}{c}
p \Delta \mathbf{x} \\
\mathbf{0}
\end{array}\right)=\left(\begin{array}{ll}
\mathbf{J}_{1} & \mathbf{J}_{2} \\
\mathbf{J}_{3} & \mathbf{J}_{4}
\end{array}\right)\left(\begin{array}{c}
\Delta \mathbf{x} \\
\Delta \mathbf{w}
\end{array}\right)
$$

dimana: $\boldsymbol{J}_{1}, \boldsymbol{J}_{2}, \boldsymbol{J}_{3}$ dan $\boldsymbol{J}_{4}$ adalah submatrikssubmatriks Jacobian yang diperoleh dengan cara melinierisasi persamaan-persamaan sistem, dan $p$ adalah operator turunan waktu (atau $d / d t$ ). Eliminasi variabel-variabel nonkeadaan dari (2) menghasilkan:

$$
p \triangle \mathbf{x}=\mathbf{A} \triangle \mathbf{x}
$$

Pada (3), $\boldsymbol{A}=\boldsymbol{J}_{\boldsymbol{1}}-\boldsymbol{J}_{\mathbf{2}} \boldsymbol{J}_{\boldsymbol{4}}^{-1} \boldsymbol{J}_{\mathbf{3}}$ biasa disebut sebagai matriks keadaan sistem (system state matrix). Investigasi mengenai kestabilan sistem tenaga akan didasarkan pada nilaieigen dari matriks keadaan ini.

\section{HASIL DAN PEMBAHASAN}

\section{A. Sistem Test dan Investigasi Awal}

Pada bagian ini dibahas hasil-hasil penyelidikan dari penggunaan PSS dan peralatan FACTS untuk meningkatkan kestabilan sistem tenaga listrik. Sistem test yang digunakan untuk pengujian adalah sistem dua-area yang memiliki 4 generator, 12 bus dengan beban total 2734 MW [12]. Diagram satu garis dari sistem tersebut diperlihatkan pada Gambar 1. 
Pada penyelidikan awal, untuk mengetahui penampilan (tingkat redaman) sistem tanpa PSS dan peralatan FACTS, peralatanperalatan tersebut tidak diikutkan dalam sistem. Perlu dicatat disini bahwa oleh karena sistem memiliki 4 mesin, maka mode elektromekanik akan berjumlah 3. Tabel 1 memperlihatkan hasil-hasil nilaieigen dan faktor-faktor partisipasi untuk ketiga mode tersebut. Pada Tabel 1 tersebut, $\lambda$ adalah nilaieigen; $f$ adalah frekwensi mode dan $\zeta$ merupakan rasio redaman. Terlihat bahwa rasio redaman dari mode inter-area adalah cukup rendah (hanya 0,0187), dan oleh karenanya perlu diperbaiki.

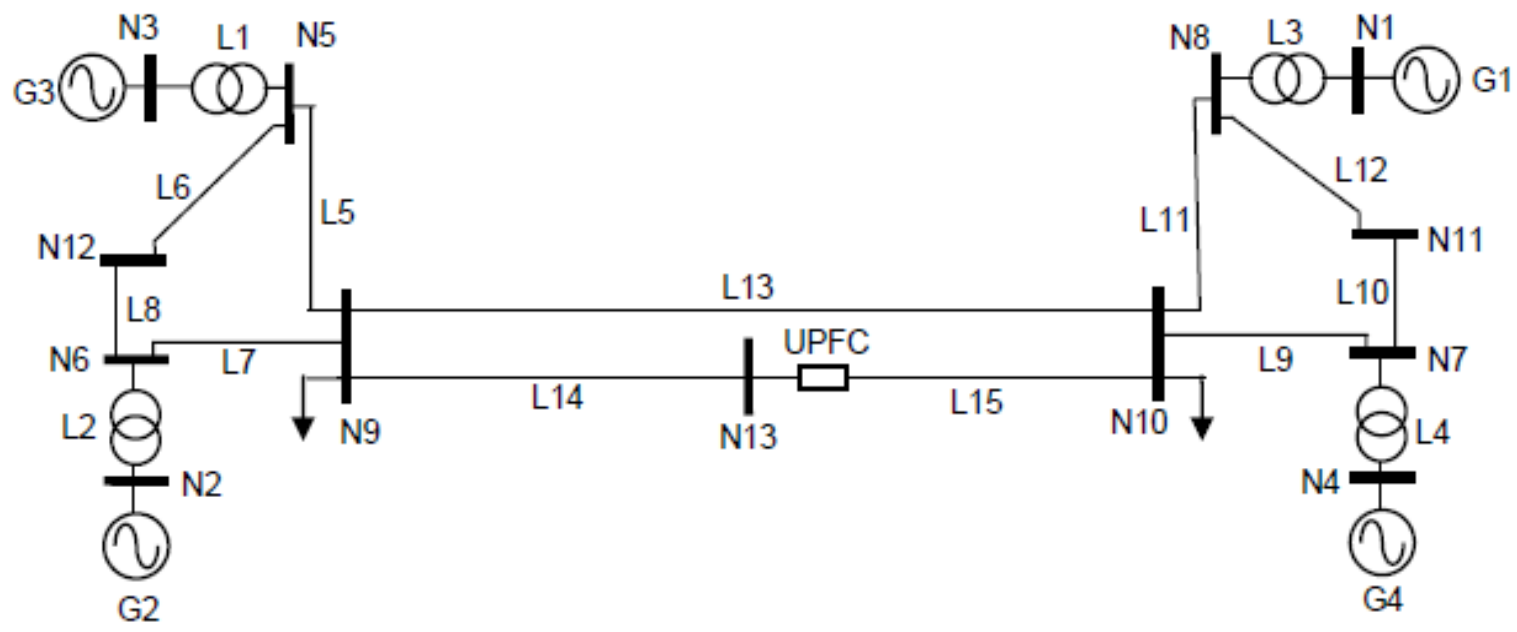

Gbr. 1 Sistem 4 generator, 12 bus

Tabel 1. Faktor partisipasi untuk sistem Gambar 1

\begin{tabular}{|c|c|c|c|}
\hline Gen. & $\begin{array}{l}\begin{array}{l}\text { Mode } 1 \\
\text { (mode lokal) } \\
\lambda=-0,7952 \pm j 7,0455 \\
f=1,12 \mathrm{~Hz} ; \zeta=\mathbf{0 , 1 1 2 2}\end{array}\end{array}$ & $\begin{array}{l}\text { Mode } 2 \\
\text { (mode lokal) } \\
\lambda=-0,7759 \pm j 6,8316 \\
f=1,09 \mathrm{~Hz} ; \zeta=0,1129\end{array}$ & $\begin{array}{l}\text { Mode } 3 \\
\text { (mode inter-area) } \\
\lambda=-\mathbf{0 , 0 5 9 5} \pm \mathrm{j} 3,1784 \\
f=\mathbf{0 , 5 1 ~ H z ; \zeta = 0 , 0 1 8 7}\end{array}$ \\
\hline 1 & 0,558466 & 0,000030 & 0,277824 \\
\hline 2 & 0,000013 & 0,570775 & 0,218618 \\
\hline 3 & 0.000001 & 0,548829 & 0,238230 \\
\hline 4 & 0,559638 & 0,000034 & 0,282552 \\
\hline
\end{tabular}

\section{B. Aplikasi PSS}

Bagian ini membahas aplikasi dari PSS dalam meningkatkan redaman dari osilasi inter-area pada sistem Gambar 1. Model untuk PSS tersebut yang diadopsi dari [1-4] diperlihatkan pada Gambar 2. Dua buah PSS (satu untuk setiap area) dipasang pada sistem
Gambar 1. Untuk memperbaiki redaman dari mode inter-area, lokasi-lokasi terbaik untuk PSS tersebut adalah pada G3 dan G4. Penentuan lokasi-lokasi PSS ini adalah berdasarkan faktor partisipasi seperti yang diperlihatkan pada Tabel 1. 


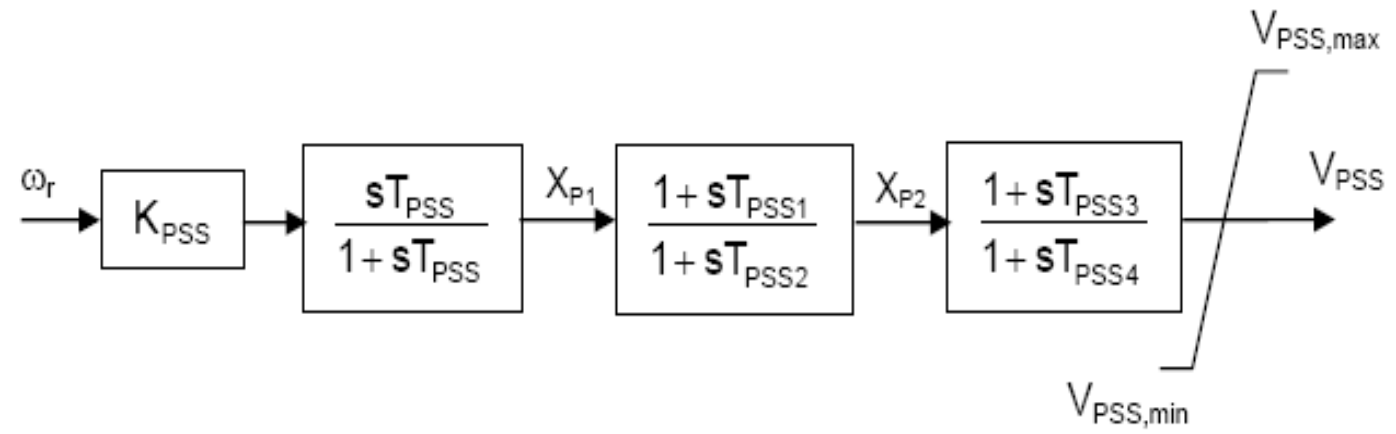

Gbr. 2 Diagram blok dari PSS

Tabel 2 memperlihatkan nilai eigen, frekwensi dan rasio redaman untuk sistem dengan dua buah PSS yang dipasang pada G3 dan G4.

Tabel 2. Nilaieigen untuk sistem dengan PSS

\begin{tabular}{|c|c|c|c|}
\hline Mode & Nilai eigen & $\mathbf{f}(\mathbf{H z})$ & $\zeta$ \\
\hline 1 & $-1,4259 \pm \mathrm{j} 6,4554$ & 1,03 & 0,2157 \\
\hline 2 & $-1,2998 \pm \mathrm{j} 6,3717$ & 1,01 & 0,1999 \\
\hline 3 & $-0,2327 \pm \mathrm{j} 3,0923$ & 0,49 & 0,0750 \\
\hline
\end{tabular}

Dengan membandingkan hasil-hasil pada Tabel 1 dan 2, terlihat bahwa dengan dipasangnya kedua PSS terdapat peningkatan dalam redaman dari mode lokal dan mode inter-area. Rasio redaman dari mode interarea terlihat meningkat lebih dari empat kali, yaitu dari 0,0187 meningkat menjadi 0,0750. Hal ini berarti bahwa dengan adanya PSS, penampilan dinamik dan kestabilan sistem menjadi semakin membaik.

\section{Aplikasi PSS dan UPFC}

Untuk lebih meningkatkan redaman osilasi dan kestabilan sistem, FDS kemudian dipasang pada UPFC yang terletak pada bus N13. Perlu dicatat bahwa UPFC tersebut sengaja dipasang dengan tujuan utama untuk mengendalikan aliran daya dan tegangan sistem pada Gambar 1. UPFC tersebut kemudian diperlengkapi dengan FDS agar ia juga dapat digunakan untuk meningkatkan redaman dari mode elektromekanik, terutama mode inter-area. Model untuk UPFC beserta FDS-nya yang diadopsi dari $[13,14]$ diperlihatkan pada Gambar 3 dan 4.

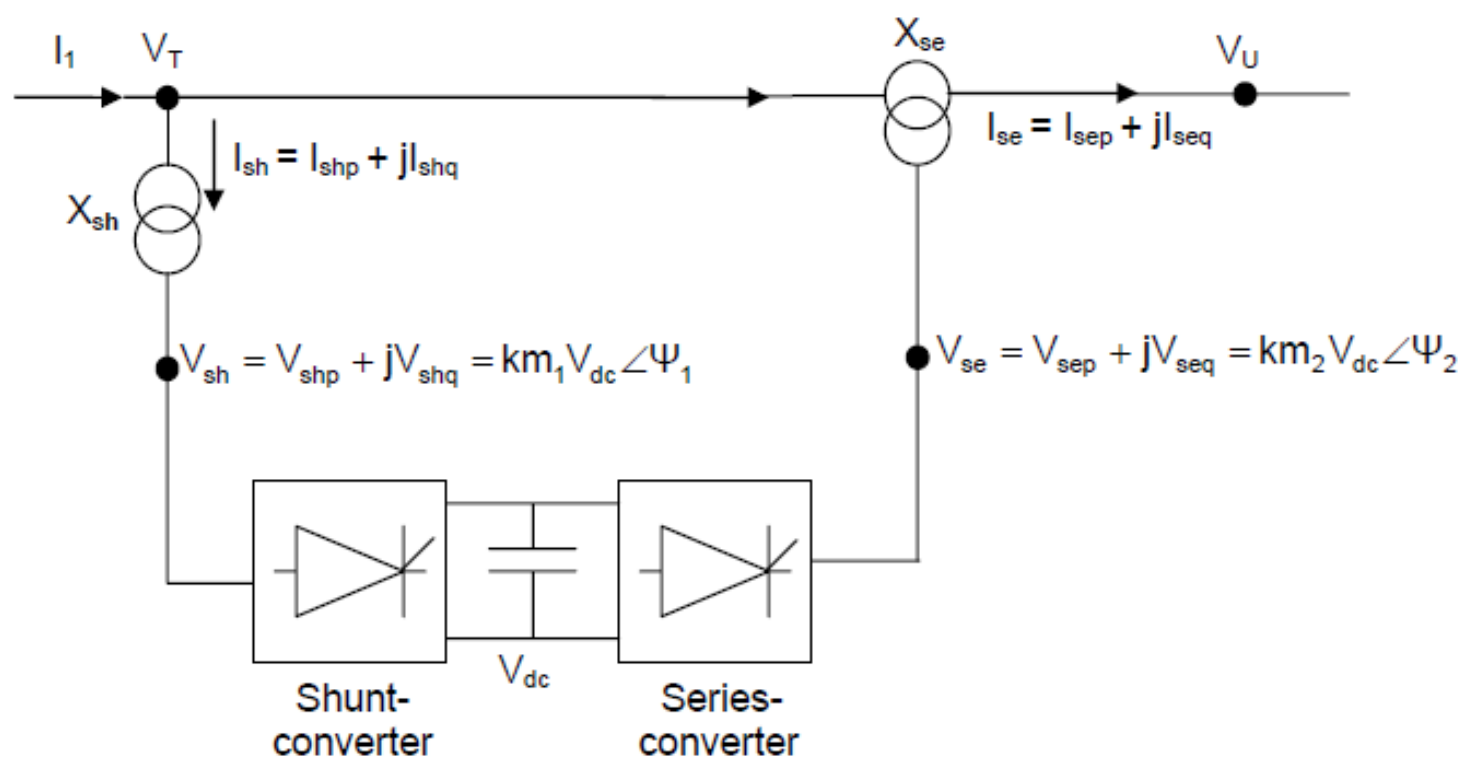

Gbr. 3 Diagram blok dari UPFC 


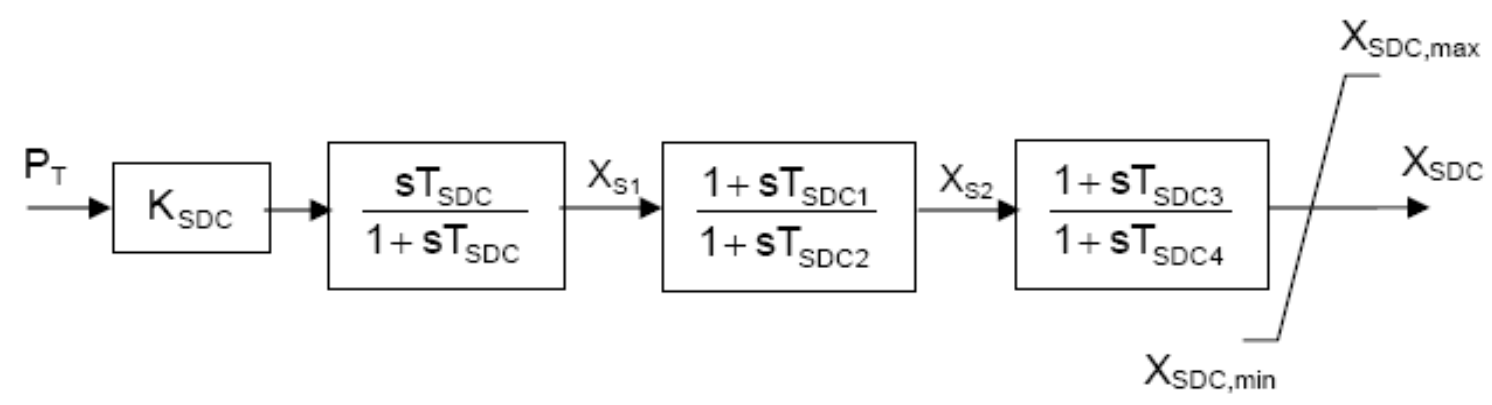

Gbr. 4 Diagram blok dari FDS

Tabel 3 memperlihatkan nilaieigen, frekwensi dan rasio redaman untuk sistem dengan dua buah PSS dan UPFC yang diperlengkapi dengan FDS. Dengan membandingkan hasil-hasil pada Tabel 2 dan 3 , terlihat bahwa dengan dipasangnya FDS pada UPFC, terdapat peningkatan lebih lanjut dalam rasio redaman dari mode inter-area, yaitu meningkat dari 0,0750 menjadi 0,1098.

Tabel 3. Nilaieigen untuk sistem dengan PSS dan UPFC

\begin{tabular}{|c|c|c|c|}
\hline Mode & Nilai eigen & $\mathbf{f}(\mathbf{H z})$ & $\boldsymbol{\zeta}$ \\
\hline 1 & $-1,4237 \pm \mathrm{j} 6,4602$ & 1,03 & 0,2152 \\
\hline 2 & $-1,3024 \pm \mathrm{j} 6,3721$ & 1,01 & 0,2002 \\
\hline 3 & $-0,3196 \pm \mathrm{j} 2,8932$ & 0,46 & 0,1098 \\
\hline
\end{tabular}

\section{Simulasi Domain Waktu}

Hasil-hasil perhitungan nilaieiegen telah mengkonfirmasi adanya peningkatan kestabilan dengan dipasangnya PSS dan FDS UPFC pada suatu sistem tenaga. Untuk mengkonfirmasi hasil ini lebih lanjut, penampilan dari PSS dan FDS UPFC pada gangguan besar dengan menggunakan simulasi domain-waktu juga akan diselidiki. Gangguan yang akan digunakan dalam penyelidikan tersebut adalah gangguan hubung-singkat tiga-fasa pada bus N11. Gangguan tersebut diinisiasi pada $\mathrm{t}=0,1 \mathrm{~s}$ dan berlangsung selama $0,1 \mathrm{~s}$ (atau waktu pemutusan gangguan adalah $0,1 \mathrm{~s}$ ).

Konfirmasi lebih lanjut dari peningkatan kestabilan sistem dapat dilihat dengan membandingkan respon-respon domainwaktu seperti yang diperlihatkan pada Gambar $5-7$. Oleh karena mode inter-area merupakan mode kritis, maka respon-respon yang digunakan adalah respon-respon transien dari beda sudut fasa tegangan antara bus N9 dan N10 (bus-bus yang menghubungkan tie-line).

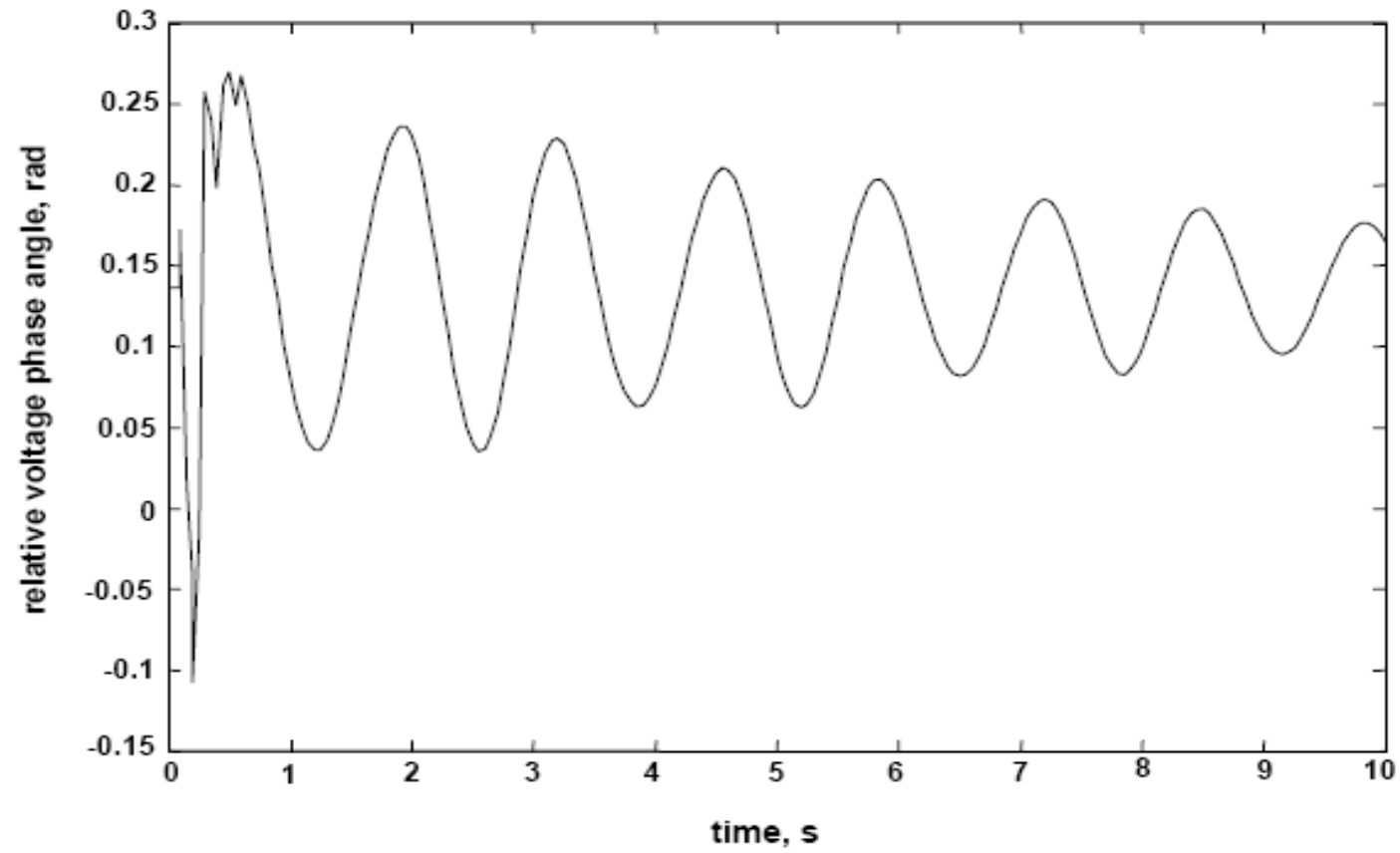

Gbr. 5 Transien untuk sistem tanpa PSS dan FDS UPFC 
Respon-respon pada Gambar 5-7 memperlihatkan bahwa tanpa PSS dan FDS UPFC, osilasi sistem sangat kurang teredam dan memerlukan waktu yang cukup lama untuk mencapai kondisi stabil (lihat Gambar 5). Gambar 6 memperlihatkan transien sistem dengan dua PSS dipasang pada sistem. Dengan adanya PSS tersebut, terlihat adanya perbaikan dalam hal waktu untuk mencapai kestabilan dari osilasi sistem (bandingkan Gambar 5 dan 6). Perbaikan lebih lanjut dalam hal waktu untuk mencapai kestabilan dapat diperoleh dengan memasang PSS dan FDS UPFC pada sistem. Pada kasus ini, osilasi sistem akan diredam secara lebih cepat (lihat Gambar 7).

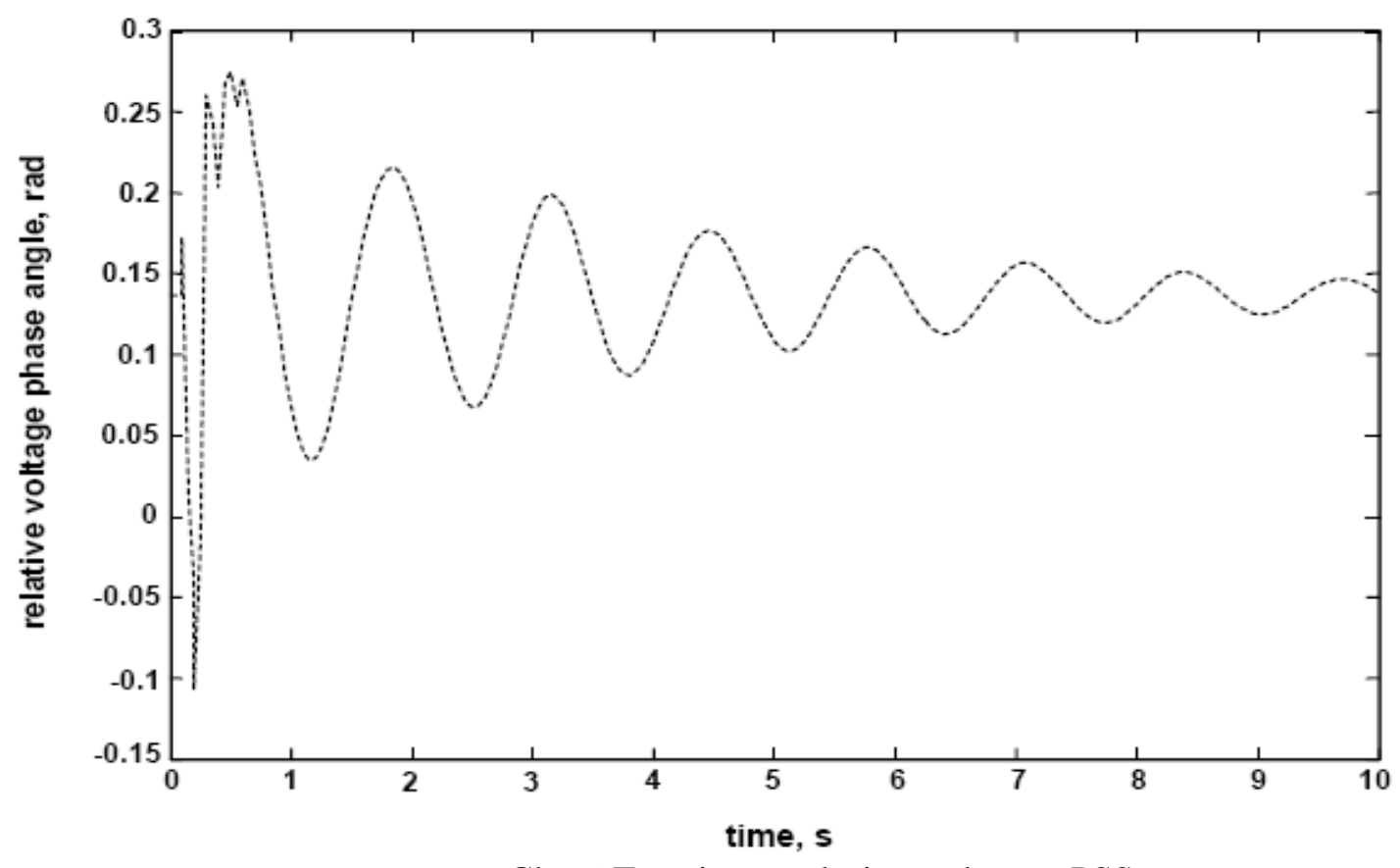

Gbr. 6 Transien untuk sistem dengan PSS

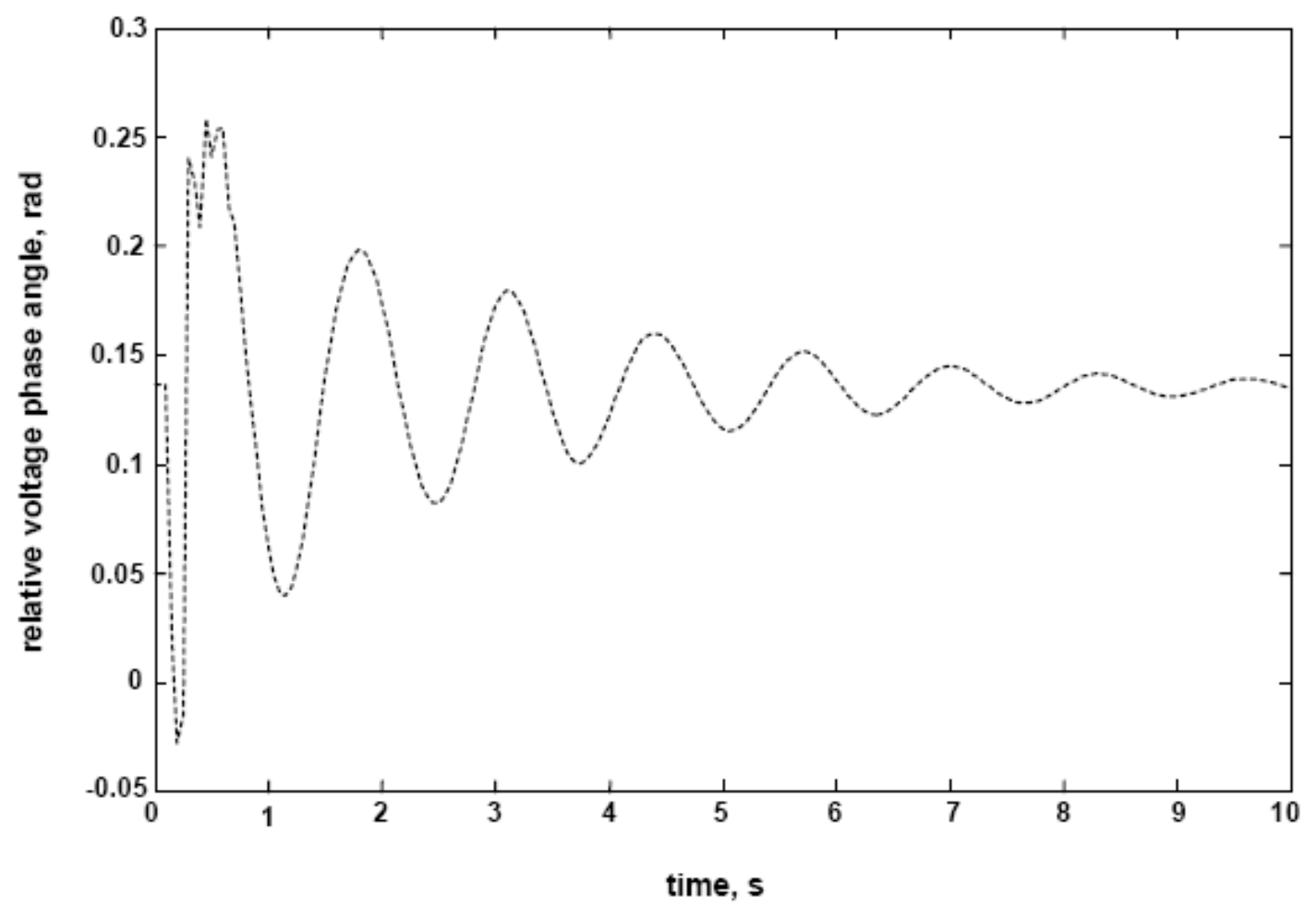

Gbr. 7 Transien untuk sistem dengan PSS dan UPFC 


\section{PENUTUP}

Aplikasi dan verifikasi dari peralatan PSS dan FDS UPFC untuk meningkatkan atau memperbaiki kestabilan sistem tenaga telah dibahas pada makalah ini. Keefektifan dari peralatan-peralatan tersebut dalam memperbaiki penampilan dinamik suatu sistem tenaga telah dikonfirmasi melalui hasil-hasil perhitungan nilaieigen. Konfirmasi lebih lanjut juga telah dilakukan melalui simulasi domain-waktu dimana gangguan besar telah digunakan untuk menginisiasi transien sistem. Perbaikan lebih lanjut dari penampilan dinamik sistem tenaga dapat dilakukan dengan cara mendisain dan mengkoordinasikan PSS dan FDS UPFC yang ada dalam sistem. Disain dan koordinasi disini berarti penentuan atau setting dari parameter-parameter PSS dan FDS UPFC adalah sedemikian sehingga peningkatan atau perbaikan kestabilan sistem tenaga menjadi optimal. Hal ini dapat menjadi topik penelitian dimasa mendatang.

\section{REFERENSI}

[1] R. Gianto and K.H. Khwee, "Neural Network-Based Stabilizer for the Improvement of Power System Dynamic Performance," TELKOMNIKA, vol. 20, no. 3 pp. 984-994, 2017.

[2] R. Gianto, "Wavelet Neural NetworkBased Stabilizer for Electric Power System Stability Improvement," Journal of Theoretical and Applied Information Technology, vol. 95, no. 19, pp. 49834991, 2017.

[3] E.S. Ali, "BAT Search Algorithm for Power System Stabilizers Design in Multimachine System," WSEAS Transactions on Power Systems, vol. 10, pp. 230-239, 2015.

[4] R. Gianto, "Application of SVC for Electromechanical Oscillation Damping Improvement in Multi-Machine Power System," WSEAS Transactions on Power Systems, vol. 14, pp. 39-48, 2019.

[5] P. Singhal, "Advanced Adaptive Particle Swarm Optimization Based SVC Controller for Power System Stability," International Journal of Intelligent
Systems and Applications, vol. 1, pp. 101-110, 2015.

[6] R. Gianto, "Application of STATCOM in Improving Dynamic Performance of Interconnected Electric Power System," IPASJ International Journal of Electrical Engineering, vol. 5, no. 6, pp. 1-8, 2017.

[7] R. Gianto, "Application of TCSC in Enhancing Dynamic Performance of Interconnected Multimachine Power System," International Journal on Electrical Engineering and Informatics, vol. 8, no. 4, pp. 787-801, 2016.

[8] R. Gianto and K.H. Khwee, "Neural Network pada Koordinasi PSS dan TCSC untuk Meningkatkan Kestabilan Sistem Tenaga Terinterkoneksi," Jurnal Nasional Teknik Elektro dan Teknologi Informasi, vol. 5, no. 4, pp. 334-340, 2016.

[9] R. Gianto and H. Priyatman, "Optimalisasi Peralatan Kontrol Sistem Tenaga Listrik Untuk Meningkatkan Kestabilan Sistem Berukuran Besar," TRANSMISI, vol. 17, no. 4, pp. 218-225, 2015.

[10] R.Z. Davarani and R. Ghazi, "Optimal Simultaneous Coordination of PSS and TCSC using Multi Objective Genetic Algorithm," Journal of Electrical System (JES), vol. 9, no. 4, pp. 410-421, 2013.

[11] M. Surekha and P.S. Puttaswamy, "Importance of FACTS Controllers in Power Systems," International Journal of Advanced Engineering Technology, vol. 2, no. 3, pp. 207-212, 2011.

[12] K.R. Padiyar, Power System Dynamics Stability and Control, John Wiley \& Sons (Asia) Pte. Ltd., Singapore, 1996.

[13] CIGRE TF 38.01.08, "Modeling of Power Electronics Equipment (FACTS) in Load Flow and Stability Programs: A Representative Guide for Power System Planning and Analysis," CIGRE , 1999.

[14] T.T. Nguyen and R. Gianto, "Optimisation-Based Control Coordination of PSSs and FACTS Devices for Optimal Oscillations Damping in Multimachine Power System," IET Gener. Transm. Distrib., vol. 1, no. 4, pp. 564-573, 2007. 